\title{
Staurosira longwanensis sp. nov., a new araphid diatom (Bacillariophyta) from Northeast China
}

\author{
Patrick Rioual ${ }^{1}$, Eduardo A. Morales ${ }^{2}$, Guoqiang $\mathrm{ChU}^{1}$, Jingtai HaN ${ }^{1}$, Dong $\mathrm{Li}^{1}$, \\ Jiaqi LiU ${ }^{1}$, Qiang LiU ${ }^{1}$, Jens MingRAM ${ }^{3} \&$ Luc ECTOR $^{4}$
}

\author{
${ }^{1}$ Key Laboratory of Cenozoic Geology and Environment, Institute of Geology and Geophysics, Chinese \\ Academy of Sciences, Beijing 100029, PR China \\ ${ }^{2}$ Herbario Criptogámico, Universidad Católica Boliviana San Pablo, Calle M. Márquez esq. Plaza Jorge Trigo \\ s/n Zona Tupuraya. P.O. Box 5381, Cochabamba, Bolivia \\ ${ }^{3}$ Helmholtz Centre Postdam GFZ German Research Centre for Geosciences, Section 5.2, Telegraphenberg, \\ D-14473 Postdam, Germany \\ ${ }^{4}$ Public Research Centre - Gabriel Lippmann, Department of Environment and Agro-biotechnologies (EVA), \\ Rue du Brill, 41, L-4422 Belvaux, Grand-Duchy of Luxembourg
}

\begin{abstract}
Staurosira longwanensis sp. nov. is described from Sihailongwan maar lake, northeast China. The morphology of this new species is documented with light and scanning electron micrographs and discussed in comparison with several small species of Fragilariaceae. Staurosira longwanensis belongs in the genus Staurosira since it shares many features with taxa currently ascribed to it such as the position and characteristics of the spines, the characteristics of the areolae and apical pore fields. Apart from the type locality, S. longwanensis also occurs in another volcanic lake in northeast China, with circumneutral and oligotrophic water. Diatom analysis of the long sedimentary record retrieved from Lake Sihailongwan indicates that S. longwanensis has been present at low relative abundances in this lake at least since the Late Pleistocene.
\end{abstract}

Key words: Araphid diatoms, Bacillariophyta, China, morphometric analysis, palaeolimnology, Staurosira longwanensis sp. nov.

\section{INTRODUCTION}

The taxonomy and circumscription of genera belonging to the Fragilariaceae have long been problematic despite major taxonomic revisions in the 1980s (WiLLIAMS \& Round 1987). Even the most commonly reported of these genera such as Staurosira EHRENB., Staurosirella (Ehrenb.) D.M. Williams et Round and Pseudostaurosira D.M. Williams et Round continue to be discussed (Morales 2001), as numerous species are emended, newly transferred (Morales 2003; EdLund et al. 2006; Garcia 2006; Hamilton \& Siver 2008; Ács et al. 2009) and new species are constantly being encountered and described (e.g. Morales 2001, 2002, 2005, 2006; Manoylov et al. 2003; Morales \& Edlund 2003; Schmidt et al. 2004; Morales \& Manoylov 2006; Williams et al. 2009; Morales et al. 2010a, b, c, 2012, 2013a, b; Cejudo-Figueiras et al. 2011). In this paper a new species, named here as Staurosira longwanensis, is described using light (LM) and scanning electron microscopy (SEM). This new species was found in Lake Sihailongwan, a volcanic lake of northeast China.

\section{Material And Methods}

Study site. Lake Sihailongwan $\left(42^{\circ} 17^{\prime} \mathrm{N}, 126^{\circ} 36^{\prime} \mathrm{E}\right)$ is a small and deep maar lake with steep rocky slopes located in the Long Gang Quaternary volcanic field (Jilin Province, NE China, Fig. 1). Detailed information on the geography, recent climate and vegetation of this region and the characteristics of its volcanic lakes can be found in MingRAm et al. (2004), Stebich et al. (2009) and Chu et al. (2011). For ecological information, the $\mathrm{pH}$, conductivity, and the concentrations for the main cations, anions and nutrients were measured on several occasions on water samples collected between 2005 and 2013. The detailed methods used for obtaining these environmental data are given in RiouAl et al. (2013). A summary of Lake Sihailongwan morphometric features and surface water quality characteristics is given in Table 1 .

Sampling. A large number of samples (including phytoplankton, epilithon, epiphyton, epipelon, off-shore surface sediments, monthly sediment traps and sediment core samples) were taken from Lake Sihailongwan between 2005 and 2013. Among all samples investigated, the new species of Staurosira was most abundant in a surface-sediment sample retrieved using a UWITEC corer from the littoral zone of the lake by $17 \mathrm{~m}$ water depth in November 2006 
(Fig. 1). Preliminary observations under the light microscope revealed that numerous live diatom cells were present in this sample. It is therefore likely that the epipelic community was sampled. Other specimens of Staurosira were investigated from a short gravity core retrieved in 1998 (SHL98-2) and a $38.8 \mathrm{~m}$-long piston core retrieved in 2001 . The short gravity core spans the last 400 years, while the long piston core spans the late Pleistocene and the entire Holocene. Details on the recovery and dating of the gravity and piston cores are given in Mingram et al. (2004) and Stebich et al. (2009), respectively.

Laboratory methods. Samples were prepared according to the standard techniques described in Battarbee et al. (2001) using hydrogen peroxide and acid cleaning. Slides for the light microscope (LM) were prepared by mounting the cleaned suspension in Naphrax ${ }^{\circledR}$. LM observations were made at $\times 1000$ magnification using a Leica DM LB2 equipped with immersion objectives (N Plan, 1.25 numerical aperture) and differential interference contrast (DIC). Photomicrographs were captured using a machine vision camera (MVC3000 from UVTEC).

For scanning electron microscope analyses, aliquots of cleaned samples from two lakes were left to dry onto glass coverslips of $12 \mathrm{~mm}$ diameter. These were mounted onto aluminum stubs using Ted Pella ${ }^{\circledR}$ double-coated carbon conductive adhesive tape and coated with gold using a Polaron SC7640 sputter coater for viewing on a LEO $1530 \mathrm{VP}$ at the State Key Laboratory of Paleobiology and Stratigraphy (Chinese Academy of Sciences, Nanjing). SEM images were captured directly in digital format.

Taxonomic metrics such as valve length, width at mid-valve and width near the apices (measured at $2 \mu \mathrm{m}$ from the tip of the valve), and stria density were taken from the LM digitized images calibrated against a slide micrometer using the public domain ImageJ software (RASBAND 2013). The form factor of each valve was measured following SIVER \& BASKETTE (2004). For SEM, areola density was measured in addition to the metrics already listed for LM. For areola density, the length of 5 five areolae was measured on 5 striae located in the middle of the valve. The mean values were converted to a number of areolae per $10 \mu \mathrm{m}$ (CORTESE \& GERSONDE 2007). In total 175 valves were measured, including 24 under the SEM.

Relative diatom abundance data in the different samples investigated were calculated from counts under LM of at least 200 valves, except for the surface sediment collected in November 2006 (holotype slide), for which over 1000 valves were counted.

Morphometric analysis. The 175 specimens investigated came from three populations: a "modern" population composed of specimens from the November 2006 epipelon sample and from off-shore surface sediment samples (Figs 2-46); a population from the short gravity core SHL98-2 (AD 1615-1960); and a population from the long piston core (1263-13,070 yrs BP). To establish if the morphological characteristics of these three populations differ from each other, single characters analyses and bivariate analyses were performed. For single characters analyses, non-overlapping notches on boxplots were used to infer statistically significant dissimilarity at the $95 \%$ confidence interval (CHAMBERs et al. 1983; PAULL et al. 2008). Notched boxplots were also used to identify outlier specimens from each population (Figs 156-160). Bivariate analyses were based on scatter plots
Table 1. Environmental characteristics of Lake Sihailongwan, the type locality of Staurosira longwanensis sp. nov. The ranges for water chemistry values were obtained from the analyses of 55 samples collected from Apr-2005 to Nov-2012 (outlier values, as defined in box-and-whisker plots, were excluded).

\begin{tabular}{|c|c|}
\hline Location & $42^{\circ} 17^{\prime} \mathrm{N}, 126^{\circ} 36^{\prime} \mathrm{E}$ \\
\hline Elevation (m a.s.1.) & 790 \\
\hline Lake area $\left(\mathrm{km}^{2}\right)$ & 0.50 \\
\hline Catchment area $\left(\mathrm{km}^{2}\right)$ & 0.70 \\
\hline Maximum water depth (m) & 50 \\
\hline $\mathrm{pH}$ & $6.3-7.1$ \\
\hline Conductivity $25^{\circ} \mathrm{C}\left(\mu \mathrm{S} . \mathrm{cm}^{-1}\right)$ & $51-78$ \\
\hline Alkalinity $\left(\mu\right.$ eq. $\left.1^{-1}\right)$ & $420-601$ \\
\hline $\mathrm{Ca}\left(\mathrm{mg} \cdot 1^{-1}\right)$ & $4.7-15.2$ \\
\hline $\mathrm{Na}\left(\mathrm{mg} . \mathrm{l}^{-1}\right)$ & $1.3-4.2$ \\
\hline $\operatorname{Mg}\left(\operatorname{mg} .1^{-1}\right)$ & $2.1-3.8$ \\
\hline $\mathrm{K}\left(\mathrm{mg} \cdot \mathrm{l}^{-1}\right)$ & $0.4-2.8$ \\
\hline $\mathrm{Cl}\left(\mathrm{mg} .1^{-1}\right)$ & $0.6-2.9$ \\
\hline $\mathrm{SO}_{4}\left(\mathrm{mg} \cdot 1^{-1}\right)$ & $4.2-6.8$ \\
\hline $\mathrm{NO}_{3}\left(\mathrm{mg} \cdot \mathrm{l}^{-1}\right)$ & $0.0-1.5$ \\
\hline Total Phosphorus $\left(\mu \mathrm{g} .1^{-1}\right)$ & $0.4-21.3($ mean 9.1$)$ \\
\hline Total Nitrogen $\left(\mu \mathrm{g} .1^{-1}\right)$ & $113-558($ mean 363) \\
\hline Dissolved silica $\left(\mathrm{mg} . \mathrm{l}^{-1}\right)$ & $0.0-0.8$ \\
\hline Dissolved Organic Carbon $\left(\mathrm{mg} .1^{-1}\right)$ & $0.1-2.6$ \\
\hline Secchi disk depth (m) & $4.0-7.6$ \\
\hline
\end{tabular}

(Fig. 161). Boxplots and scatterplots were drawn using R (R Development Core Team 2013).

\section{RESUlts}

\section{Staurosira longwanensis Rioual, E. Morales et ECTOR sp. nov. (Figs 2-155)}

\section{Description}

In LM ( Figs 2-143): Frustules rectangular in girdle view, forming chains (Figs 40-42). Valves isopolar with inflated central area, poles rostrate, less so in small valves which tend towards narrowly elliptical; length 4.6-17.8 (22.5) $\mu \mathrm{m}$, width 2-3.9 $\mu \mathrm{m}$. Stermum often very narrow but sometimes lanceolate. Striae alternate, parallel or slightly radial towards the apices; stria density $11.2-14.8$ striae per $10 \mu \mathrm{m}$. Plastids not seen.

In SEM (Figs 144-155): Striae uniseriate, composed of up to 9 areolae, of which 2-4 located on mantle 


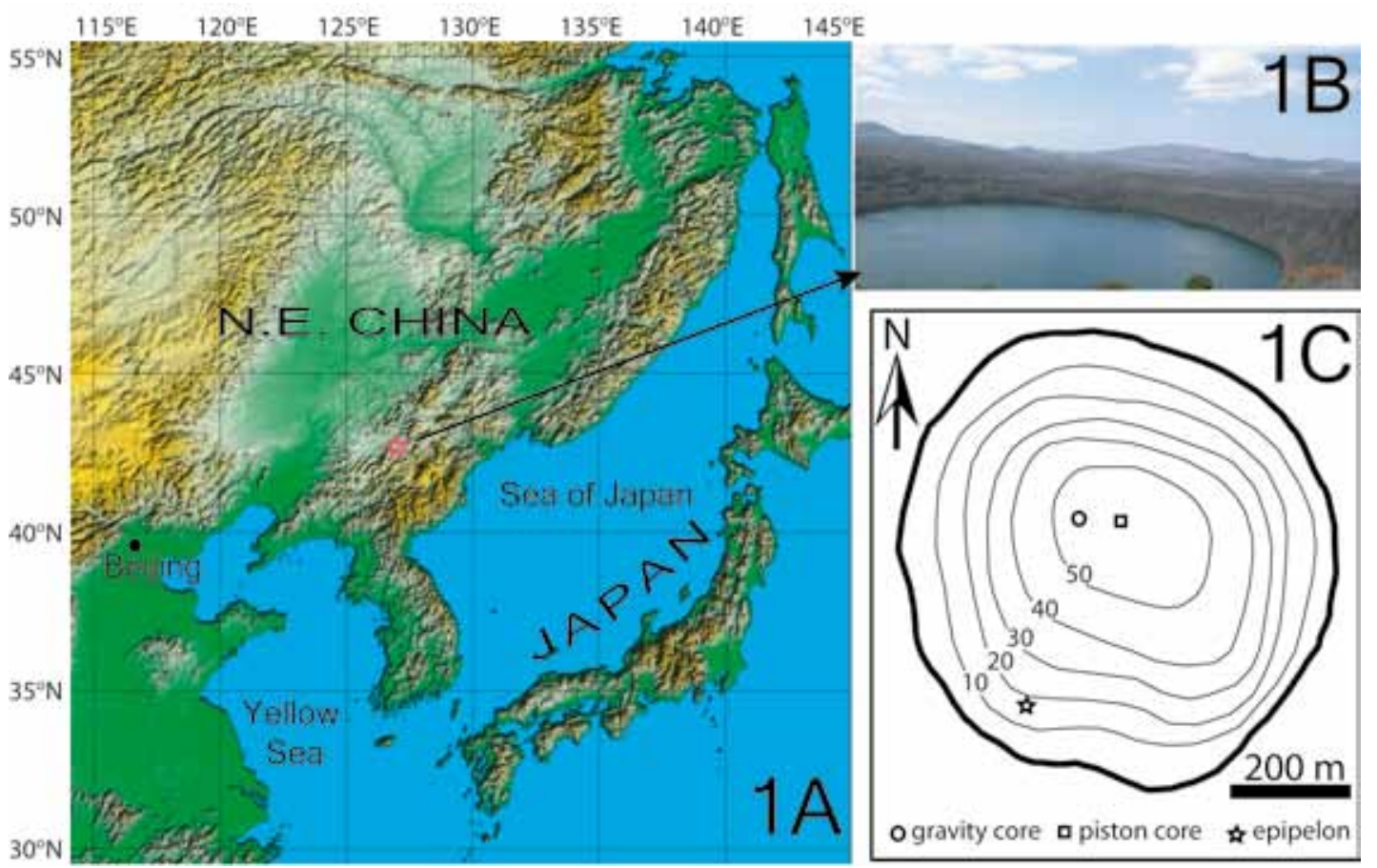

Fig. 1. (A) Location of Lake Sihailongwan in Northeast China; (B) view of the lake; (C) bathymetry of the lake and sampling sites (the interval of the isobathic curves is $10 \mathrm{~m}$ ).

(Fig. 147). Areolae vary in shape from oval (Figs 146-149) to transapically extended (Figs 144, 145, $150,151)$; areolae bear delicate vola, finely branched and extending inner periphery of areolae (Figs 152$154)$; density is $49-59$ areolae per $10 \mu \mathrm{m}$. Spines solid, spatulate (Figs 146, 149) or poorly developed and conical (Fig. 148), located between the striae. Apical pore field located at transition between valve face and valve mantle, well developed even in small valves (Figs 144-151), composed of several rows (up to 5) of small rimmed poroids (Figs 148, 152, 153). Rimoportulae absent. Girdle bands bear one row of perforations (Fig. 155).

Etymology: The epithet of the new species refers to "long wan" the Chinese name for the crater lakes of the Long Gang volcanic field in Jilin Province and which means "Dragon bowl" in English.

Holotype: Slide IGGDC-DB-SIHA-0611! (holotype specimen illustrated in Fig. 17, located using England Finder N48/2 or at coordinates 48.1 and 103.7 with a Leica DM LB2 light microscope).

Isotype: Slide BM 101 673, Natural History Museum, London, United Kingdom.

Type locality: CHINA, Jilin Province, Long Gang volcanic Field, Lake Sihailongwan, $790 \mathrm{~m}, 42^{\circ}$ $17^{\prime} 01^{\prime \prime} \mathrm{N}, 126^{\circ} 36^{\prime} 07^{\prime \prime} \mathrm{E}$. Surface sediment, collected $19^{\text {th }}$ November 2006 by Dr. Patrick Rioual, IGG-CAS, Beijing. Institute of Geology \& Geophysics Diatom Collection, coded in the Index Herbariorum as IGGDC (http://sciweb.nybg.org/science2/IndexHerbariorum. asp).
Ecology and associated diatom species: Lake Sihailongwan has circumneutral and oligotrophic water (Table 1). Diatom analyses of many modern samples collected since 2005 in Lake Sihailongwan indicate that $S$. longwanensis is most abundant in the epipelon of the deep littoral zone (holotype collected at $17 \mathrm{~m}$ water depth). It is absent or only sporadically present in epilithon and epiphyton (on filamentous green algae) samples collected near the shore. It is also absent from the periphyton communities collected on the surface of sediment trap buoys.

LM analysis of the surface-sediment sample used as holotype slide yielded 77 taxa. The sample was dominated by planktonic species including Discostella stelligeroides (HuSTEDT) HouK et KLEE (32\%), Handmannia balatonis (PANtocseK) KulikovskiY et SolaK $(10.6 \%)$ and Fragilaria nanoides LANGEBERTALOT (1.2\%). Interestingly, the same three taxa dominate the assemblages of all sediment trap samples collected so far (over the period 2002-2012) as well as the late Holocene sedimentary record since $\sim 3600$ yrs BP. Among the benthic species found in the holotype slide $(46.2 \%)$, the most abundant species were Staurosirella pinnata (EHRENBERG) D.M. Williams et Round sensu Morales (2001) (15.4\%), Pseudostaurosira microstriata (MARCINIAK) Flower (5.9\%), Eolimna raederae (LANGE-BERTALOT) LANGEBertalot et Kulikovskiy (4.1\%), Staurosira construens var. venter (EHRENBERG) P.B. HAMILTON sensu MORALES (2001) (2.2\%), Pseudostaurosira trainorii E. Morales (2.1\%), Nupela vitiosa (SchimansKi) LANGE-BERTALOT $(2.0 \%)$ and the new species described here $(2.9 \%)$. 

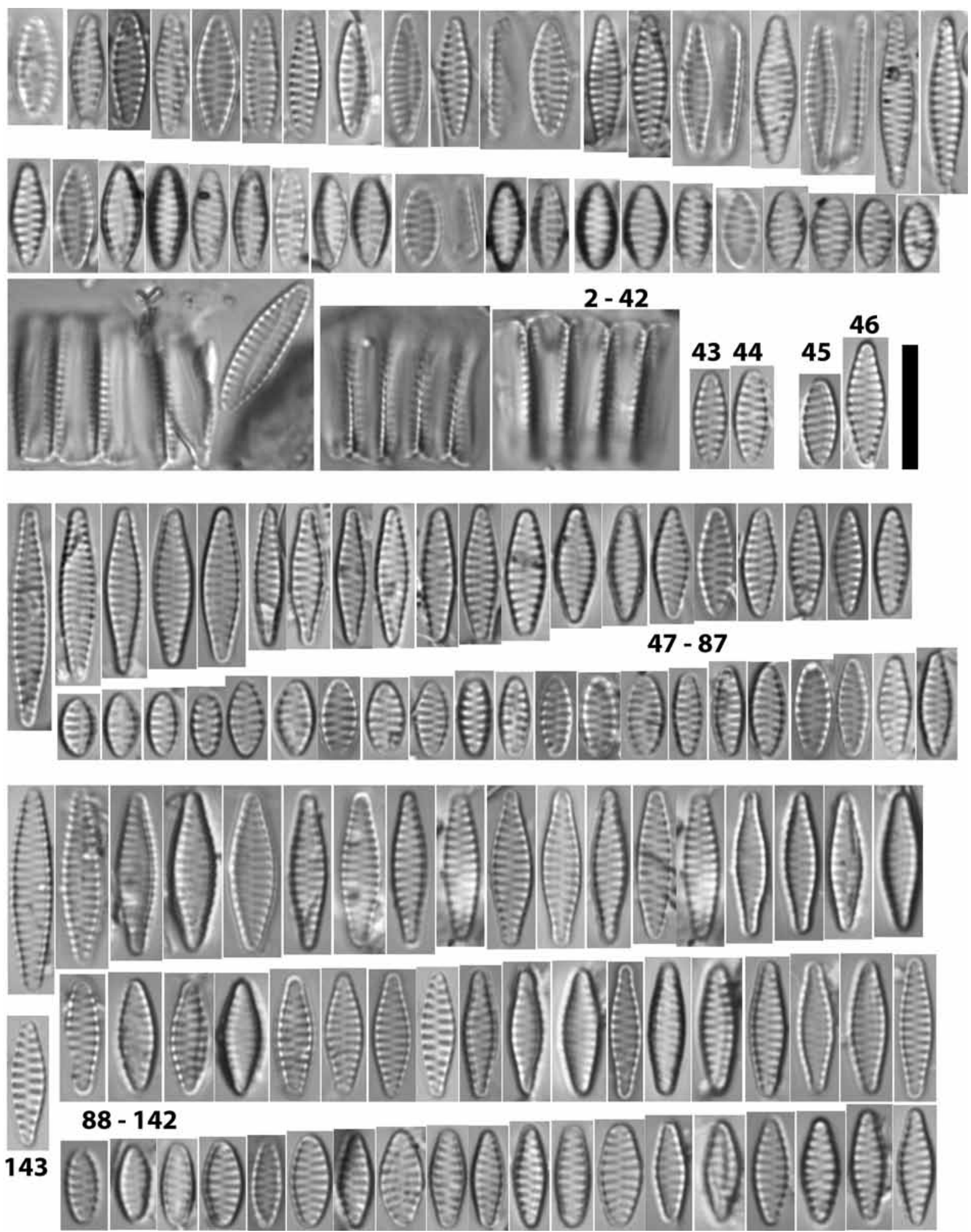

Figs 2-143. Light microscopy images of Staurosira longwanensis from Lake Sihailongwan: (2-42) population from an epipelon sample (17 $\mathrm{m}$ water depth) collected in November 2006; (43-44) and (45-46) specimens found in surface sediment samples (50 m water depth) collected in October 2005 and August 2007, respectively; (47-87) specimens from the short gravity core SHL98-2 (AD 1615-1960); (88-142) late Holocene specimens from the long piston core (1263-3487 yrs BP). 143. Late Pleistocene specimen (13 070 yrs BP). Scale bar $10 \mu \mathrm{m}$. 


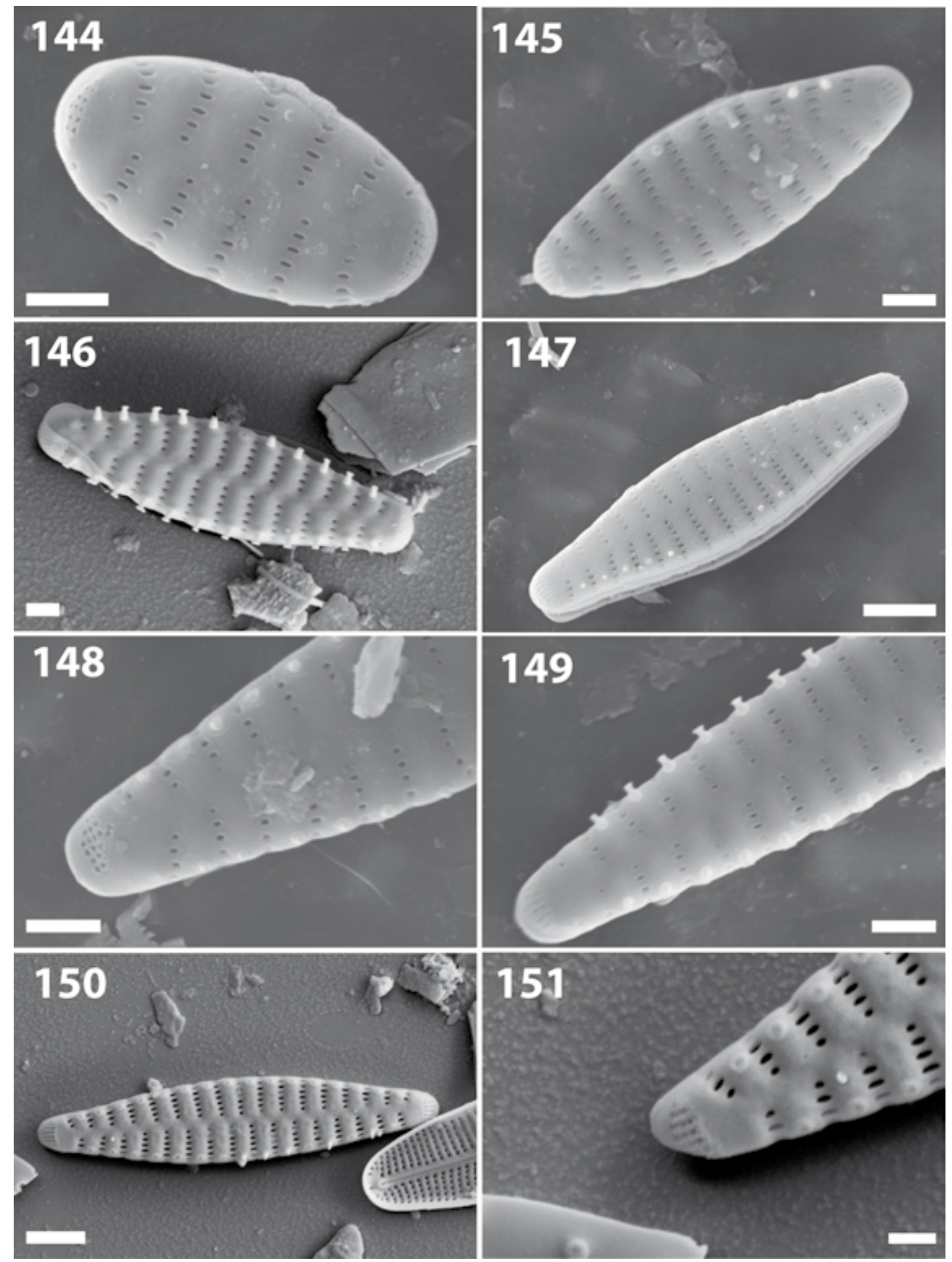

Figs 144-151. Scanning electron microscope images of Staurosira longwanensis showing external view of valves of various length and outline and the characteristics of axial area, striae and spines: $(144)$ short elliptic valve; $(145,146,149)$ detail of the spines; $(148,149,151)$ detail of the valve apices showing the characteristics of the striae and apical pore fields; (151) detail of figure 150 showing broken spines that suggest a solid structure. Scales bars $2 \mu \mathrm{m}$ (Figs 147, 150); $1 \mu \mathrm{m}$ (Figs 144, 145, 146, 148, 149); $200 \mathrm{~nm}$ (Fig 151). 

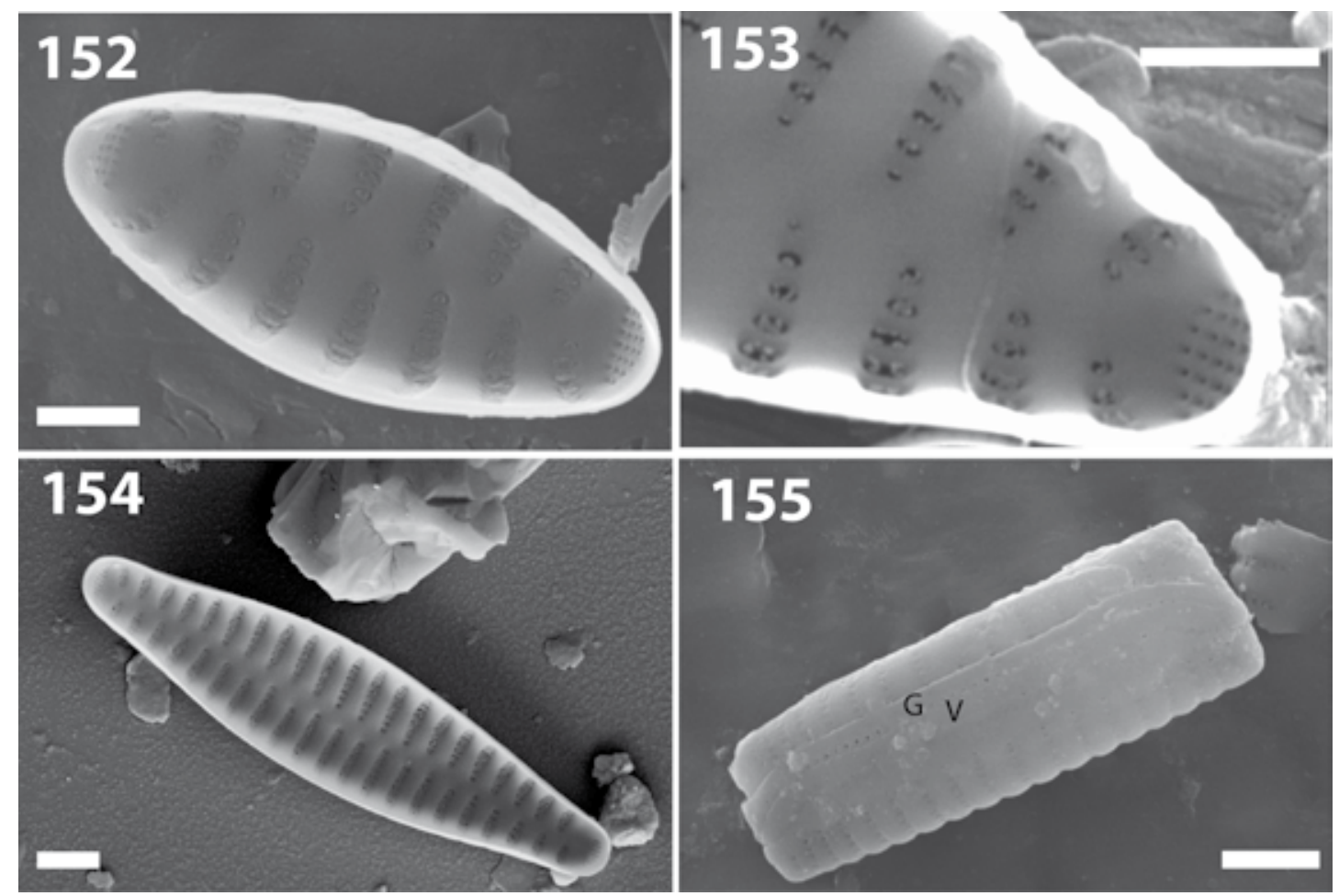

Figs 152-155. Scanning electron microscope images of Staurosira longwanensis: (152-154) internal view of valves of various length and outline; (153) characteristics of the apical pore field and the volae; (155) side view of a frustule showing detail of the cingulum with a valvocopula ' $V$ ' and a perforated girdle band 'G'. Scales bars $2 \mu \mathrm{m}$ (Figs 154, 155); $1 \mu \mathrm{m}$ (Figs 152, 153).

Distribution: Until now S. longwanensis was only found in Lake Sihailongwan and in the surfacesediment of another maar lake in the Longang volcanic field (Longquan longwan maar lake), that has similar water chemistry.

Morphometric analysis: Notched boxplots show that there are no significant differences in morphometry between the valves of $S$. longwanensis found in modern and subfossil populations (Figs 156-160). Bivariate analyses (Fig. 161) also show that the three populations (modern, gravity core, piston core) cannot be clearly separated and occupy the same size trajectories. Form factor values are controlled by valve length, while valve width has low influence. Variation in stria density is not related to the other metrics. Bivariate analyses on the subset of valves observed under the SEM $(n=21)$, indicate that areola density is not significantly correlated to the other morphometric variables (result not shown).

\section{Discussion}

An extensive literature search was conducted and revealed a number of taxa that appear morphologically similar under the LM to Staurosira longwanensis and could therefore be confused with this new species.
By its valve outline Staurosira longwanensis resembles several other fragilarioid taxa such as Staurosirella confusa E. MoRALES, Staurosirella oldenburgiana (Hustedt) E. Morales, Pseudostaurosira tenuis E. Morales et EdLund and Pseudostaurosira elliptica (Schumann) Edlund, E. Morales et S.A. Spaulding. However, the combination of morphological features as presented above differs from taxa belonging to the genera Staurosirella D.M. Williams et Round and Pseudostaurosira (GRunow) D.M. Williams et Round. The genus Staurosirella has well-developed costae and striae composed of slit-like areolae while Pseudostaurosira has wide areolae and spines located between the interstriae, features that are not present in Staurosira longwanensis.

Staurosira longwanensis is a representative of Staurosira because it shares with taxa currently allocated to this genus several features such as the position and characteristics of the spines (on the costae), the characteristics of the areolae (small oval to lineate openings with and internal vola occlusion) and apical pore fields (composed of rimmed poroids). Staurosira longwanensis is different from other species of Staurosira because of its unique combination of characters which are its valve outline, well-developed apical pore fields, solid spines and the row of perforations on the girdle bands.

Small specimens of $S$. longwanensis may be confused with Staurosira construens var. venter. However, short valves of $S$. construens var. venter are 

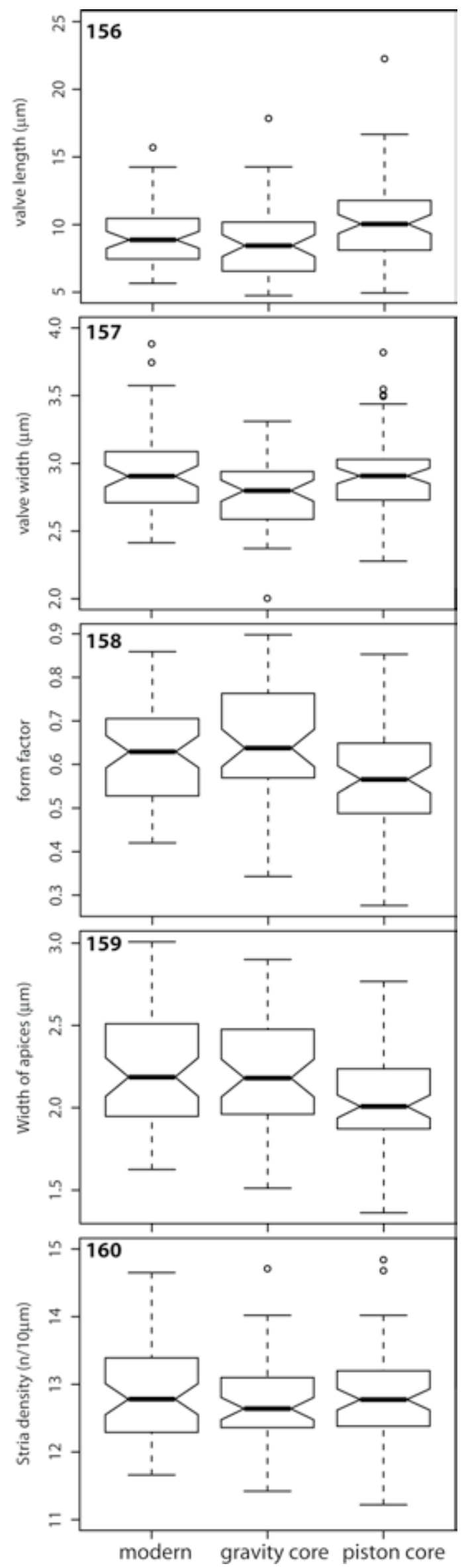

wider, frequently possess a wider sternum and have a more elliptical outline (Morales 2010). The apical pore fields are also much more reduced in this taxon (Morales 2001).

Another species with morphology comparable to that of S. longwanensis is Staurosira oldenburgioides (Lange-Bertalot) Lange-Bertalot, Kulikovskiy et Wiткоwski, but it differs from $S$. longwanensis in having a higher stria density (15-17 instead of 12-15 in $10 \mu \mathrm{m})$, wider valve $(3.3-4.2$ instead of $2-3.9 \mu \mathrm{m})$ and more raised costae (LANGe-Bertalot et MetZeltin 1996).

Fragilaria construens var. javanica HUSTEDT and Fragilaria capensis Grunow have a valve outline and a general appearance very similar to $S$. longwanensis. However, F. construens var. javanica has a wider central area and higher stria density (1619 in $10 \mu \mathrm{m}$, Hustedt Diatom Study Centre 2013) while $F$. capensis has much coarser areolae, girdle bands perforated by a double row of poroids and was described from a marine environment (WITKOWSKI et al. 1995). It remains unclear what the taxonomic position of $F$. construens var. javanica and $F$. capensis should be as these taxa have no rimoportula while species belonging to Fragilaria sensu stricto have one (TuлI \& WiLLIAMS 2006).

The variability in the shape of areolae observed in $S$. longwanensis is a character shared with other species of Staurosira such as Staurosira stevensonii Manoylov, E. Morales et Stoermer (Manoylov et al. 2003), Staurosira dimorpha E. Morales, EdLund \& S.A. Spaulding and Staurosira ambigua E. Morales, Edlund et S.A. Spaulding (Morales et al. 2010a).

The apical pore fields of $S$. longwanensis are well-developed and similar to those of Staurosira grigorszkyi Ács, E. MoRALEs et ECTOR (Ács et al. 2009) and Staurosira obtusa (Hustedt) M. Garcia (Garcia 2006). The apical pore fields are located on the apex right to the edge between the valve face and the mantle, as in most Staurosira species (GARCIA 2006).

The spines of $S$. longwanensis are solid and spatulate and are surrounded at the base by a ring of silica with projections. By contrast, spines in Staurosira are often hollow as in S. ambigua (MORALES et al. 2010a), Staurosira elliptica (Schumann) D.M. Williams et Round sensu Haworth (Haworth 1975;

Figs 156-160. Box plots showing the quantile distributions of valve characters for Staurosira longwanensis observed in the 3 populations investigated: modern $(n=57)$, gravity core $(n=49)$ and piston core $(\mathrm{n}=67)$ : (156) valve length; (157) valve width; (158) form factor; (159) width of apices; (160) stria density (= number of striae in 10 $\mu \mathrm{m})$. The $25-75$ percent quartiles (excluding outliers) are drawn using a box. The median is shown with a horizontal line inside the box. The whiskers represent the upper and lower "inner fence", i.e. are drawn from the edge of the box up to the largest/lowest data point less than 1.5 times the box height. Outliers, i.e. values outside the inner fences, are shown as circles if they lie further from the edge of the box than 3 times the box height. 


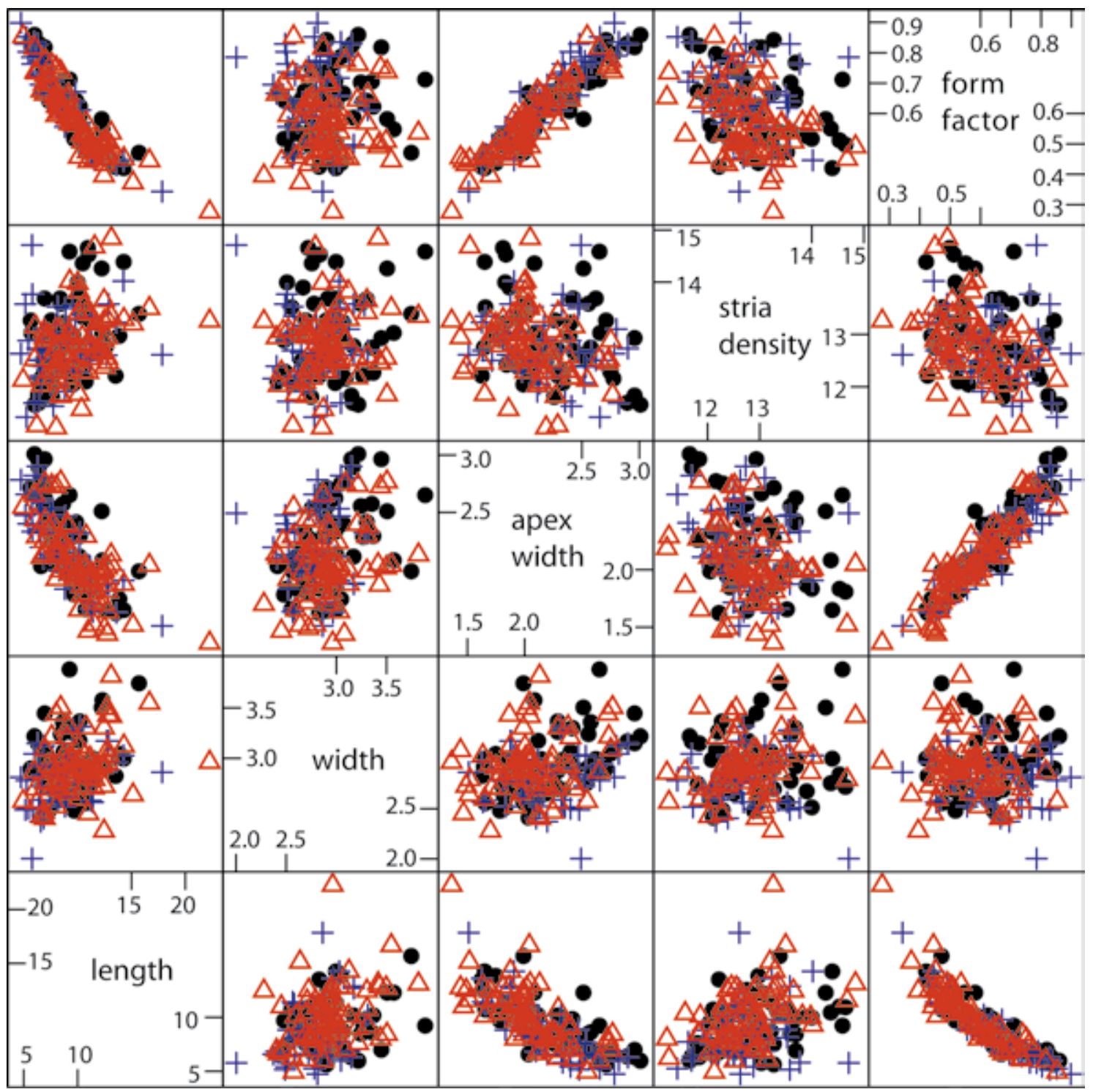

Fig. 161. Matrix of biplots of morphometric characters comparing populations of Staurosira longwanensis from the modern (black filled circles), gravity core (blue crosses) and piston core (red open triangles) populations. Measurements are in $\mu \mathrm{m}$ for valve length, width and width of apex. Stria density is in number of striae per $10 \mu \mathrm{m}$.

Morales 2001) Staurosira incerta E. Morales, Staurosira construens EHRENB. (Morales 2006), Staurosira construens var. binodis (EHRENB.) P.B. Hamilton (Morales 2005) and S. construens var. venter sensu Morales (Morales 2001). The only other species of Staurosira reported to have solid spines is Staurosira kjotsunarum E. Morales, Novais et Ector (Morales et al. 2012).

The presence of perforations on the girdle band is another peculiar feature of $S$. longwanensis as Staurosira species generally have copulae free of ornamentation (Round et al. 1990; GARCIA 2006). However, Morales et al. (2010a) recently described $S$. dimorpha with a double row of poroids on the girdle bands.

Staurosira longwanensis appears to be most abundant in the deep littoral zone of the lake where it co-occurs with other small Fragilariaceae species.
Previous studies focusing on diatom distribution along a water-depth gradient also reported a middepth assemblage dominated by small Fragilariaceae in various lakes from Europe (CANTONATI et al. 2009) and North America (Kingsbury et al. 2012). Light availability and water turbulence, which decrease as water depth increases, strongly influence diatom depth zonation (FLower et al. 2004). In Lake Baikal, numerous rare and endemic taxa have been reported from the deep littoral zone, stable but light limited, by contrast with the shallow littoral zone dominated by cosmopolitan species (Flower et al. 2004; KuLIKOVSKIY et al. 2012).

In conclusion, we described a new species of fragilarioid diatom using LM and SEM. Our observations suggest that $S$. longwanensis is endemic to northeastern China and may be associated with the deep littoral zone. This study contributes to the 
immediate need to document and illustrate diversity to facilitate research on diatom biogeography, ecology and palaeoecology in China.

\section{ACKNOWLEDGEMENTS}

Dr Yan Fang (State Key Laboratory of Paleobiology and Stratigraphy, Nanjing) is thanked for assistance with the SEM. This research was supported by the "Strategic Priority Research Program" of the Chinese Academy of Sciences, Climate Change: Carbon Budget and Relevant Issues (grant \# XDA05120201-2) and the National Science Foundation of China (grants \# 40502018 and \# 40872113).

\section{REFERENCES}

Ács, É.; Morales, E.A.; Kiss, K.T.; Bolla, B.; PlenkovićMoraj, A.; Reskóné, M.N. \& Ector, L. (2009): Staurosira grigorszkyi nom. nov. (Bacillariophyceae) an araphid diatom from Lake Balaton, Hungary, with notes on Fragilaria hungarica Pantocsek. - Nova Hedwigia 89: 469-483.

Battarbee, R.W.; Jones, V.J.; Flower, R.J.; Cameron, N.G.; Bennion, H.; Carvalho, L. \& Juggins, S. (2001): Diatoms. - In SMOL, J.P.; BIRKS, H.J.B. \& LAST, W.M. (eds): Tracking environmental change using lake sediments, Volume 3: terrestrial, algal, and siliceous indicators. - pp. 155-202, Kluwer Academic Publishers, Dordrecht.

Cantonati, M.; Scola, S.; Angeli, N.; Guella, G. \& Frassanito, R. (2009): Environmental controls of epilithic diatom depth-distribution in an oligotrophic lake characterized by marked water-level fluctuations. - Eur. J. Phycol. 44: 15-29.

Cejudo-Figueiras, C.; Morales, E.A.; Wetzel, C.E.; Blanco, S.; Hoffmann, L. \& Ector, L. (2011): Analysis of the type of Fragilaria construens var. subsalina (Bacillariophyceae) and description of two morphologically related taxa from Europe and the United States. - Phycologia 50: 67-77.

Chambers, J.M.; Cleveland, W.S.; Kleiner, B. \& Turkey, P.A. (1983): Graphical methods for data analysis. 395 pp., Wadsworth International Group, Boston.

Chu, G.; Sun, Q.; Wang, X.; Liu, M.; Lin, Y.; XIE, M.; Shang, W. \& LiU, J. (2011): Seasonal temperature variability during the past 1600 years recorded in historical documents and varved lake sediment profiles from northeastern China. - The Holocene 22: 785-792.

Cortese, G. \& Gersonde, R. (2007): Morphometric variability in the diatom Fragilariopsis kerguelensis: Implications for Southern Ocean paleoceanography. - Earth Planet. Sc. Lett. 257: 526-544.

Edlund, M.B.; Morales, E.A. \& Spaulding, S.A. (2006): The type and taxonomy of Fragilaria elliptica Schumann, a widely misconstrued taxon. - In WitKowsKI, A. (ed): Proceedings of the eighteenth international diatom symposium, Miedzyzdroje, Poland $2^{\text {nd }}-7^{\text {th }}$ September 2004. - pp. 53-99, Biopress Limited, Bristol.

Flower, R.J.; Pomazkina, G.; Rodionova, E. \& Williams, D.M. (2004): Local and meso-scale diversity patterns of benthic diatoms in Lake Baikal. - In Poulin, M. (ed): Proceedings of the seventeenth international diatom symposium. Ottawa, Canada, 25th-31th August 2002. - pp. 69-92, Biopress Limited, Bristol.

Garcia, M. (2006): The transfer of Fragilaria obtusa
Hustedt to the genus Staurosira Ehrenberg (Bacillariophyceae). - Phycol. Res. 54: 87-93.

Hamilton, P.B. \& Siver, P.A. (2008): The type for Fragilaria lancettula Schumann 1867 and transfer to the genus Punctastriata as P. lancettula (Schum.) Hamilton \& Siver comb. nov. - Diatom Res. 23: 355-365.

Haworth, E.Y. (1975): A scanning electron microscope study of some different frustules forms of the genus Fragilaria found in Scottish late-glacial sediments. - Brit. Phycol. J. 10: 73-80.

Hustedt Diatom Study Centre (2013): Available from: https://web-apps.awi.de/Hustedt-Diatoms/Curator/ [Accessed: 20 September 2013].

Kingsbury, M.V.; Laird, K.R. \& Cumming, B.F. (2012): Consistent patterns in diatom assemblages and diversity measures across water-depth gradients from eight Boreal lakes from north-western Ontario (Canada). - Freshwater Biol. 57: 1151-1165.

Kulikovskiy, M.S.; Lange-Bertalot, H.; Metzeltin, D. \& Witkowski, A. (2012): Lake Baikal: hotspot of endemic diatoms I. - Iconographia Diatomologica 23: 1-607.

Lange-Bertalot, H. \& Metzeltin, D. (1996): OligotrophieIndikatoren. 800 Taxa repräsentativ für drei diverse Seen-Typen Kalkreich - Oligodystroph Schwach gepuffertes Weichwasser. - Iconographia Diatomologica 2: 1-390.

Manoylov, K.M.; Morales, E.A. \& Stoermer, E.F. (2003): Staurosira stevensonii sp. nov. (Bacillariophyta), a new taxon from Florida, USA. - Eur. J. Phycol. 38: $65-71$.

Mingram, J.; Allen, J.R.M.; Brüchmann, C.; Liu, J.; Luo, X.; Negendank, J.F.W.; NowaczyK, N. \& Schettler, G. (2004): Maar- and crater lakes of the Long Gang Volcanic Field (N.E. China) - overview, laminated sediments, and vegetation history of the last 900 years. - Quatern. Int. 123-125: 135-147.

Morales, E.A. (2001): Morphological studies in selected fragilarioid diatoms (Bacillariophyceae) from Connecticut waters (U.S.A.). - Proc. Acad. Nat. Sci. Phila. 151: 105-120.

Morales, E.A. (2002): Studies in selected fragilarioid diatoms of potential indicator value from Florida (USA) with notes on the genus Opephora Petit (Bacillariophyceae). - Limnologica 32: 102-113.

Morales, E.A. (2003): On the taxonomic status of the genera Belonastrum and Synedrella proposed by Round and Maidana (2001). - Cryptogamie Algol. 24: 277-288.

Morales, E.A. (2005): Observations of the morphology of some known and new fragilaroid diatoms (Bacillariophyceae) from rivers in the USA. Phycol. Res. 53: 113-133.

Morales, E.A. (2006): Staurosira incerta (Bacillariophyceae) a new fragilarioid taxon from freshwater systems in the United States with comments on the structure of girdle bands in Staurosira Ehrenberg and Staurosirella Williams et Round. - In OgnJanovaRumenova, N. \& Manoylov, K. (eds): Advances in phycological studies. Festschrift in Honour of Prof. Dobrina Temniskova-Topalova. - pp. 133-145, Pensoft Publishers \& University Publishing House, Sofia-Moscow.

Morales, E.A. (2010): Staurosira construens. In Diatoms of the United States. Available from: http:// westerndiatoms.colorado.edu/taxa/species/ 
staurosira_construens_var._venter [Accessed 17 September 2013].

Morales, E.A. \& EdLund, M.B. (2003): Studies in selected fragilariod diatoms (Bacillariophyceae) from Lake Hovsgol, Mongolia. - Phycol. Res. 51: 225-239.

Morales, E.A.; Edlund, M.B. \& Spaulding, S.A. (2010a): Description and ultrastructure of araphid diatom species (Bacillariophyceae) morphologically similar to Pseudostaurosira elliptica (Schumann) Edlund et al. - Phycol. Res. 58: 97-107.

Morales, E.A. \& Manoylov, K.M. (2006): Staurosirella incognita Morales et Manoylov sp. nov., a nonspiny species from North America, with an emended description of Staurosirella Williams et Round (Bacillariophyceae). - In Witkowski, A. (ed.): Proceedings of the eighteenth international diatom symposium, Miedzyzdroje, Poland $2^{\text {nd }}-7^{\text {th }}$ September 2004. - pp. 325-336, Biopress Limited, Bristol.

Morales, E.A.; Buczkó, K.; Wetzel, C.E.; Novais, M.H.; Ognjanova-Rumenova, N.; Hoffmann, L. \& Ector, L. (2013a): Transfer of Staurosira grunowii to Staurosirella. - Diatom Res. Available from: http:// dx.doi.org/10.1080/0269249X.2013.804446

Morales, E.A.; Guerrero, J.M.; Wetzel, C.E.; Sala, S. \& EстоR, L. (2013b): Unravelling the identity of Fragilaria pinnata Ehrenberg and Staurosira pinnata Ehrenberg: research in progress on a convoluted story. - Cryptogamie Algol. 34: 89-102.

Morales, E.A.; Manoylov, K.M. \& Bahls, L.L. (2010b): Three new araphid diatoms (Bacillariophyta) from rivers in North America. - Proc. Acad. Nat. Sci. Phila. 160: 29-46.

Morales, E.A.; Novais, M.H.; Chávez, G.; Hoffmann, L. \& EcTOR, L. (2012): Diatoms (Bacillariophyceae) from the Bolivian Altiplano: three new araphid species from the Desaguadero River draining Lake Titicaca. - Fottea 12: 41-58.

Morales, E.A.; Wetzel, C.E. \& Ector, L. (2010c): Two shortstriated species of Staurosirella (Bacillariophyceae) from Indonesia and the United States. - Polish Bot. J. 55: 107-117.

Paull, T.M.; Hamilton, P.B.; Gajewski, K. \& LeBlanc, M. (2008): Numerical analysis of small Arctic diatoms (Bacillariophyceae) representing the Staurosira and Staurosirella species complexes. - Phycologia 47: 213-224.

R Development Core Team (2013): R: A language and environment for statistical computing. R Foundation for Statistical Computing, Vienna, Austria. Available from: http://www.R-project.org/ [Accessed 20 September 2013].

RASBAND, W.S. (2013): ImageJ, version 1.46r. U. S. National Institutes of Health, Bethesda, Maryland, USA. Available from: http://imagej.nih.gov/ij/ [Accessed 20 September 2013].

Rioual, P.; Lu, Y.; Yang, H.; Scuderi, L.; Chu, G.; Holmes, J.; ZHU, B. \& YANG, X. (2013): Diatom-environment relationships and a transfer function for conductivity in lakes of the Badain Jaran Desert, Inner Mongolia, China. - J. Paleolimnol. 50: 207-229.

Round, F.E.; Crawford, R.M. \& Mann, D.G. (1990): The Diatoms. Biology and Morphology of the Genera. 747 pp., Cambridge University Press, Cambridge.

Schmidt，R.; Lange-Bertalot， H. \& Klee， R. (2004):
Staurosira parasitoides sp. nova and Staurosira microstriata (Marciniak) Lange-Bertalot from surface sediment samples of Austrian alpine lakes. Algological Studies 114: 1-9.

Siver, P.A. \& BAsketTe, G. (2004): A morphological examination of Frustulia (Bacillariophyceae) from the Ocala National Forest, Florida, USA. - Can. J. Botany 82: 629-644.

Stebich, M.; Mingram, J.; Han, J. \& Liu, J. (2009): Late Pleistocene spread of (cool-) temperate forests in Northeast China and climate changes synchronous with the North Atlantic region. - Global Planet Change 65: 56-70.

Tus, A. \& Williams, D.M. (2006): Examination of the type material of Synedra rumpens $=$ Fragilaria rumpens, Bacillariophyceae. - Phycol. Res. 54: 99-103.

Williams, D.M.; Chudaev, D.A. \& Gololobova, M.A. (2009): Punctastriata glubokoensis spec. nov., a new species of 'fragilarioid' diatom from Lake Glubokoe, Russia. - Diatom Res. 24: 479-485.

Williams, D.M. \& Round, F.E. (1987): Revision of the genus Fragilaria. - Diatom Res. 2: 267-288.

WitKowski, A.; Lange-Bertalot, H. \& Witak, M. (1995): Diatom taxa of unusual frustule structure belonging to the genus Fragilaria. - Fragm. Florist. Geobot. 40: 729-741.

\footnotetext{
(C) Czech Phycological Society (2014)
}

Received October 16, 2013

Accepted December 13, 2013 